\title{
Why Do I Have to Pay My Income Taxes? The Effects of Taxpayers' Perceived Value on Commitment to Pay in Light of the Possibility of Tax Evasion
}

Mehdi Khademi Grashi Assistant Professor, Institute for Management and Planning Studies.

\begin{abstract}
Voluntary payment of taxes is a sweet wish of the governments and tax organizations. Adopting a nascent approach, public sector marketing tries to help these organizations in attracting and persuading the target groups by applying the concept of marketing democracy. In this way, managing the mindset of the target community can make paying taxes easy and satisfactory. The present research studies the effects of taxpayers' perceived value and their commitment to pay by considering the moderating variable of the possibility of perceived tax evasion. Taxable companies comprised the statistical population of the study and the required data were gathered by applying survey method. Based on the findings acquired by structural equations, the perceived value has a direct and positive impact on tax payers' commitment and satisfaction. Another noteworthy finding of this study shows that perceived value of tax payment is relatively high; however, taxpayers' perception of the possibility of tax evasion with no serious consequences reduces its impact in practice. The results of this research can change the policymakers' viewpoints regarding tax revenues by taking public sector marketing into consideration.
\end{abstract}

Keywords: Perceived Value, Satisfaction, Tax Commitment, Tax Avoidance, Public Sector Marketing. 


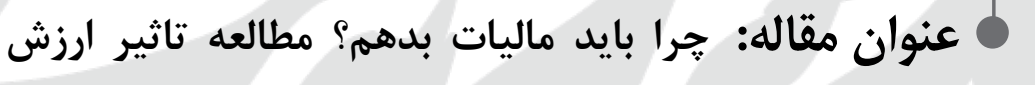

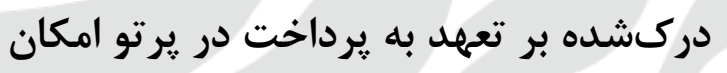

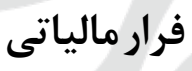

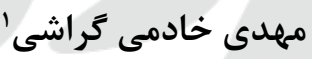

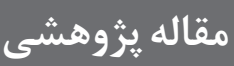

دريافت: و و

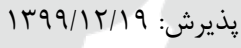

\section{جكيل:}

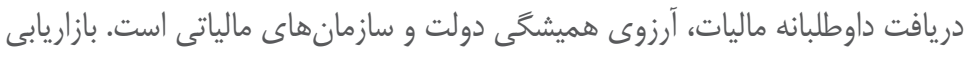

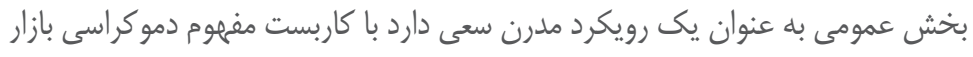

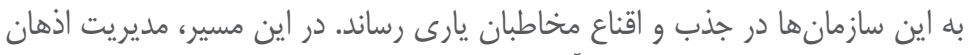

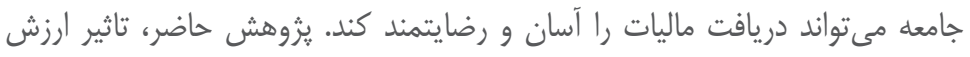

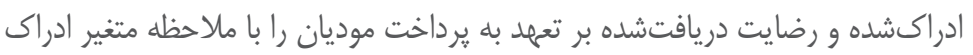

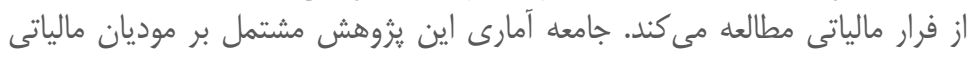

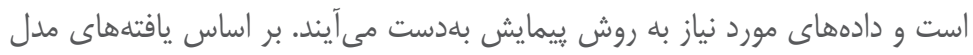

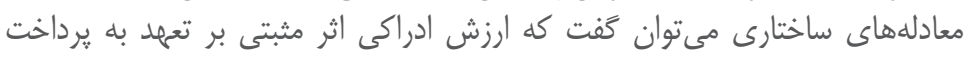

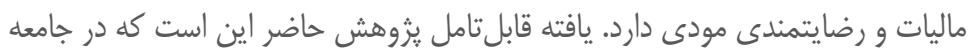

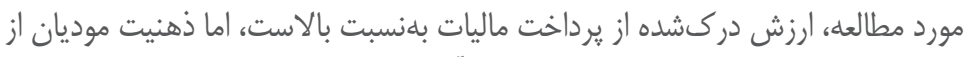

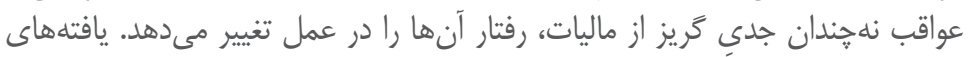

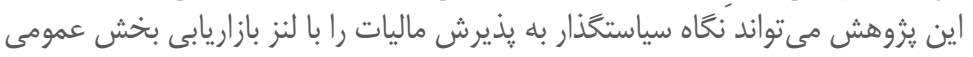
متحول كند.

$$
\begin{aligned}
& \text { كليدوازهها: ارزش ادراكى، رضايتمندى، بازاريابى بخش عمومى، }
\end{aligned}
$$

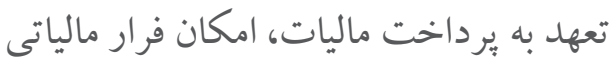

m.khademi@imps.ac.ir

1. استاديار خروه مديريت، مو سسه عالى آموزش و يثوهش مديريت و برنامهريزى. 


\section{مقدمه}

بيشتر يزوهشهاى انجامشده در مورد فرايند مالياتستانى، بلويزه ماليات بر ارزشافزوده، داراى

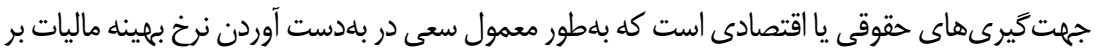

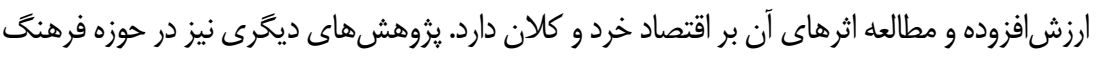

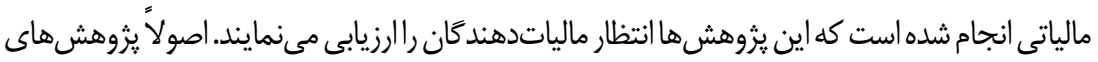
حوزه يذيرش مالياتى بر مبناى تحليل هاى اجتماعى و روانشناسى انجام مى گيرد و ادبيات در اين زمينه

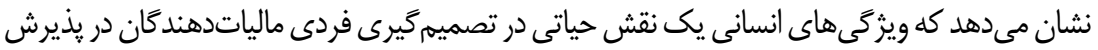
و يرداخت ماليات ايفا مى كنند (Bobek et al., 2007; Bird et al., 2008). هرجند يثروهش حوزه يذيرش مالياتى يافتههاى رشتههاى مختلف را با هم ادغام مى كنند، ولى هنوز هيج توافقى در ياسخ به اين يرسش وجود ندارد كه جرا مردم ماليات مىيردازند يا نمىيردازند؟ (Devos, 2013). برخلاف ديدگًاه رايج در سازمانهاى دولتى و سازمان امور مالياتى كه مالياتدهى را جزئى از وظايف شهروندى مى داند كه بايد در قبال دولت و جامعه انجام شود، از ديدكًاه بازاريابى بخش عمومى،

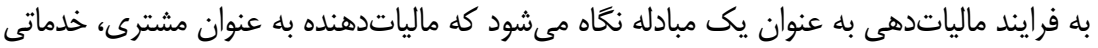
را از دولت به عنوان عرضهكننده دريافت مى كند و ماليات بها و ارزشى است كه مشترى مىيردازد (كاتلر و لى، هوسا()، و مالياتدهندًان بايد به اظهارنامه مالياتى به جيزى فراتر از رهايى از جريمه نحاه

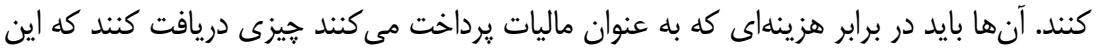

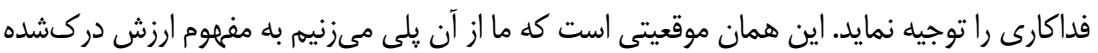

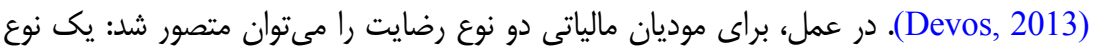
رضايت از فرايند مصرف ماليات توسط دولت است و نوع ديخر، رضايت از فرايند جمعآورى ماليات. مورد اول كه نقش بسيار مهمى در تصميمگيرىهاى شخصى افراد دارد، غالباً از ديد يزوهشخران ينهان مانده است (Chen, 2010). دانش بازاريابى تنها فلسفه وجودى سازمانها و شركتها را تامين نيازها و خواستههاى مشتريان و مخاطبان خود مى داند و با همين ديد است كه در بيشتر يروهشها رابطه ارزش دركشده با رفتار مطلوب مورد بررسى قرار گرفته است (Sweeney, 2007). بازاريابى بخش عمومى به عنوان شاخهاى نو به سازمانهاى دولتى و عمومى بله مثابه يك سازمان تجارى نغاه

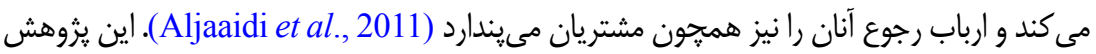


سعى دارد با بكار كيرى اين مفاهيه، به يرسش جِحونكى شكل گيرى ارزش و رضايت دركشده موديان

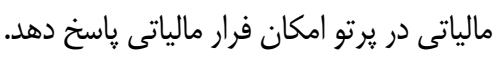

\section{مبانى نظرى :ثزوهش}

در ياسخ به اينكه حرا برخى ماليات مى يردازند و برخى از آن فرار مى كنند، مفهوم "إيذيرش

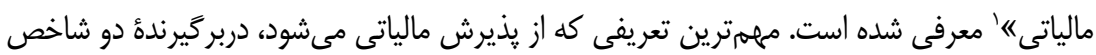
بلوقتت بودن و درست بودن اظهارنامه مالياتى است (Alm et al., 2010; Devos, 2013). برخى

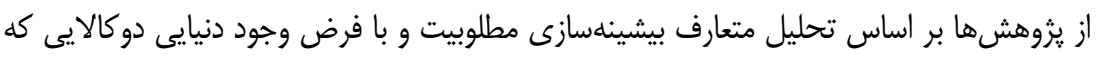

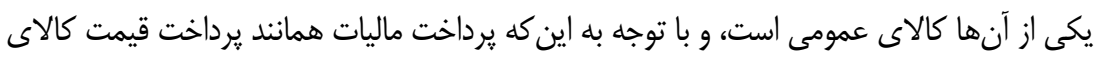

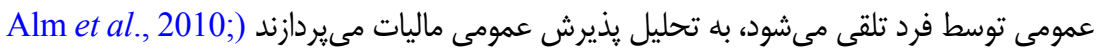
(Mancharoen, 2015

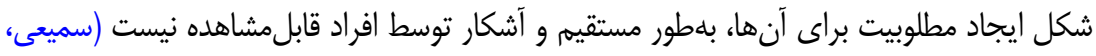

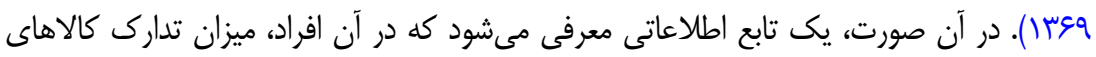

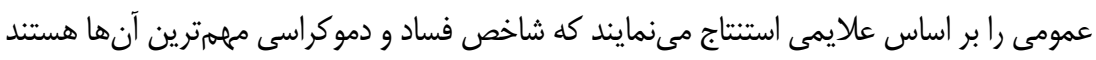
.(Bird et al., 2008)

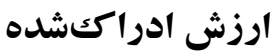

امروزه اطاعت از دولت در صورتى مشروع و قابلقبول است كه دولت براى خواستههاى مردم

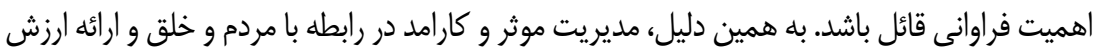

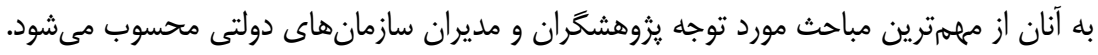

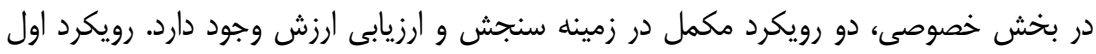

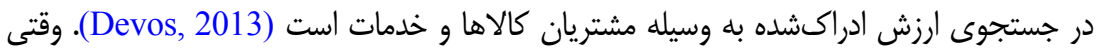

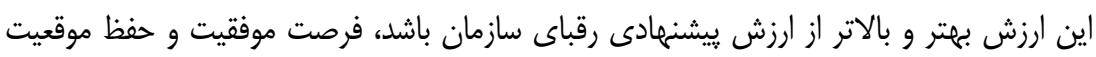

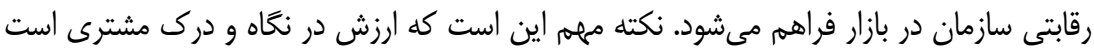

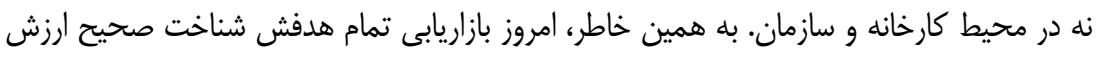

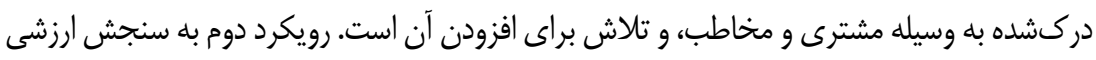

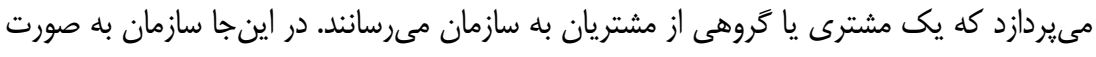




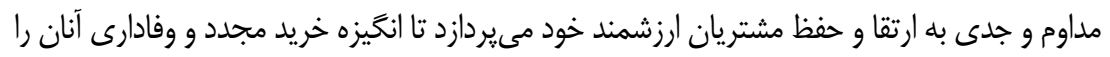
افزايش دهد (Evans, 2002). مدلهاى بسيارى براى ارزيابى ارزش دركشده ارائه شده است، كه

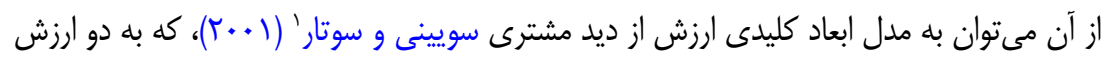

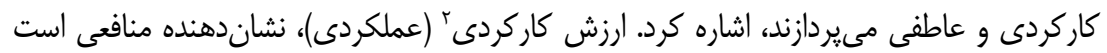

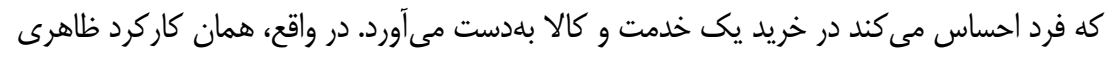

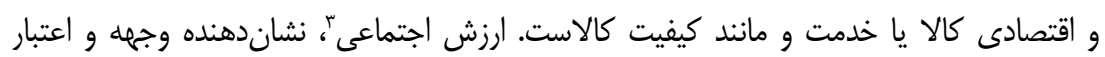

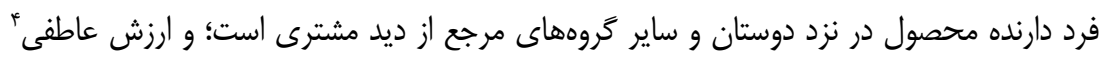

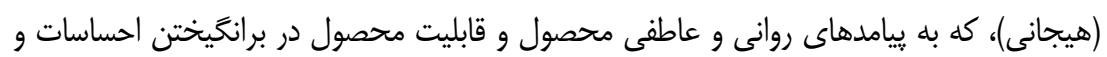

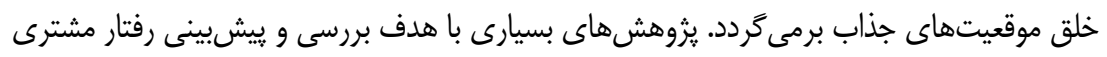

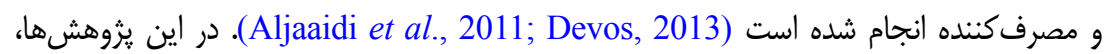

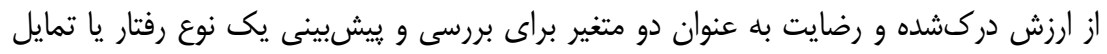

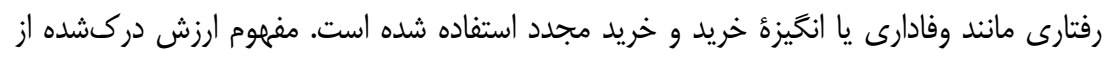

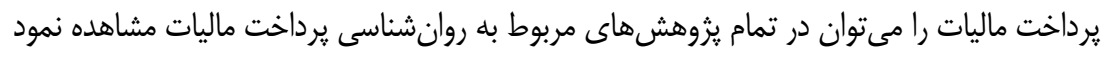

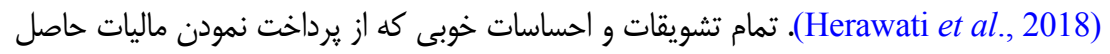

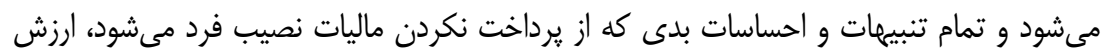
دركشدة اين كار است (Mancharoen, 2015).

\section{رضايت مودى}

رضايت را مىتوان نتيجة ارزيابى 》آنهه هسته با 》آنجه بايد مىبوده بيان نمود. كاتلر رضايت

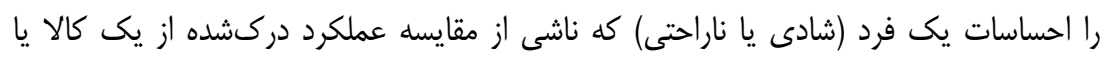
خدمت با انتظارهاى مشترى از اين عملكرد است، تعريف مى كند (Kotler \& Keller, 2006).

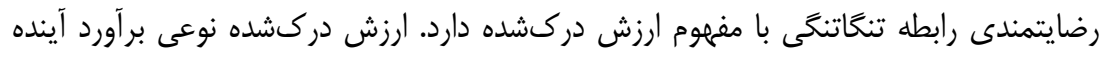

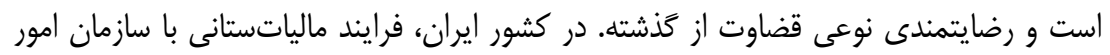

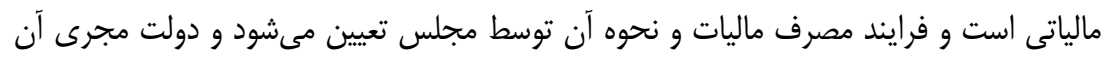
است. در اين ثروهش، رضايت موديان از فرايند و موارد مصرف ماليات كه خارج از كنترل و حيطه

1. Sweeney \& Soutar

2. Function Value

3. Social Value

4. Emotional Value 
سازمان امور مالياتى است، رضايت نوع اول نام مى گيرد، به اين دليل كه در يزوهشهاى مالياتى دانى

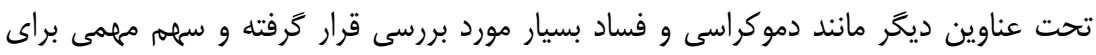
آن در نظر كرفته شده است (Sukesi \& Yunaidah, 2020). مفاهيمى مانند دموكراسى، تمر كز و و نبود تمركز قدرت، و ميزان فساد همه از شاخصهاى مهمى هستند كه بر تصميمها و نوع نحرش

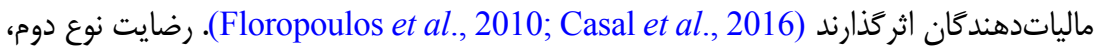

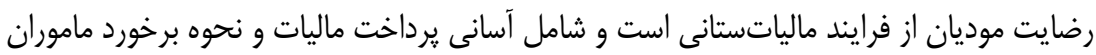

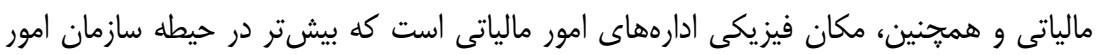

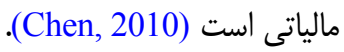

\section{وفادارى و تعهد به يرداخت موديان}

وفادارى يك تعهد ماندًار و عميق نسبت به خريد يا مشتري دوبارهٔ يك محصول يا خدمت

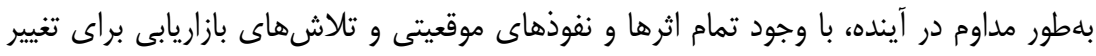

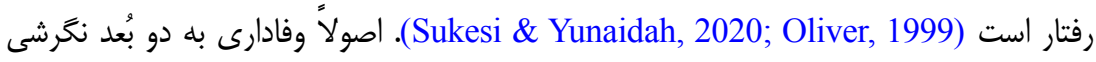

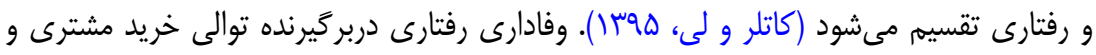

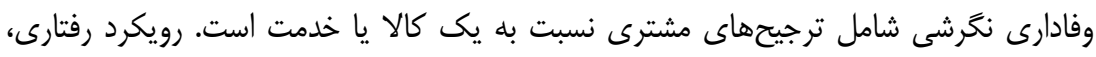

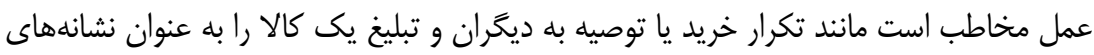

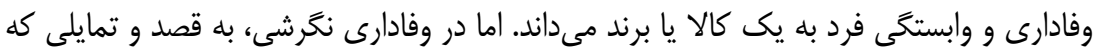

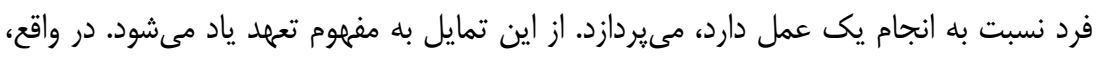

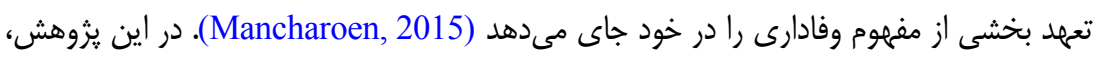

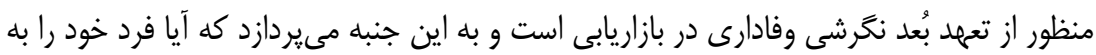
يرداخت دقيق و بلموقع ماليات موظف مى داند يا خير؟

\section{تعميم و تطبيق مدل ارزش در ككشده در يرداخت ماليات}

اصولاً بكاركيرى تجارب و مدلهاى بخش تجارى در بخش عمومى و دولتى موافقان و

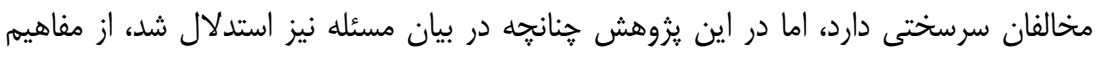

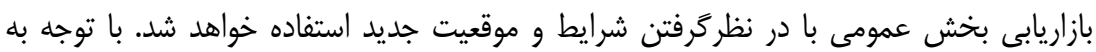

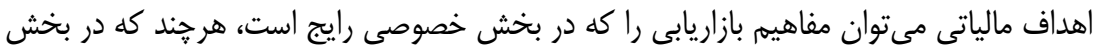

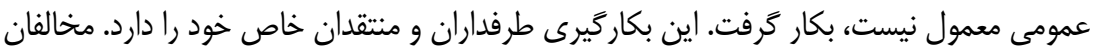


جنين استدلال مى كنند كه فعاليتهاى دولت با بخش تجارى بهذات متفاوت است، اما كاتلر و

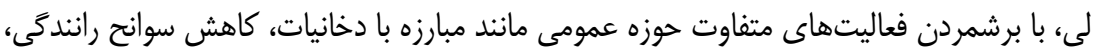

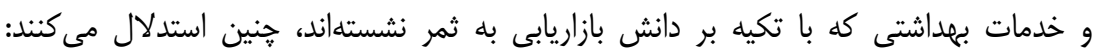

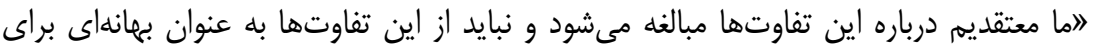

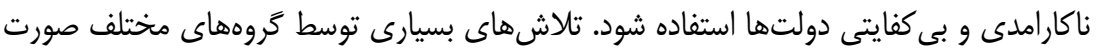
مى گيرد تا كارايى و تاثير اقدامهاى دولت بهبود يابد (Kotler \& Lee, 2007: 13).

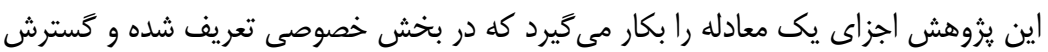

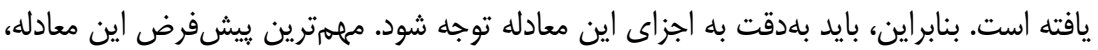

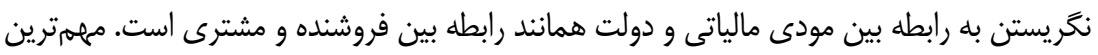

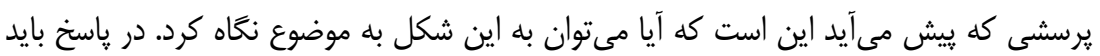

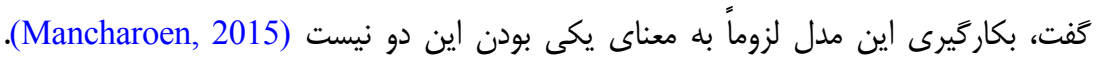

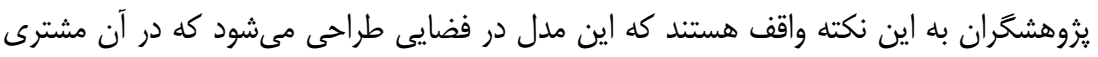

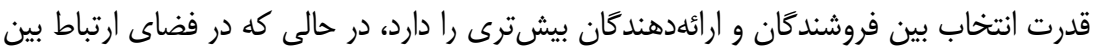

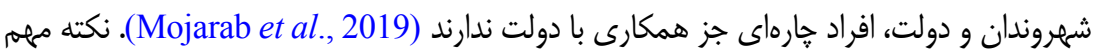
اين است كه اكرجه موديان خارهاى جز همكارى ندارند، ولى ميزان همكارى آنان با دولت جيزى

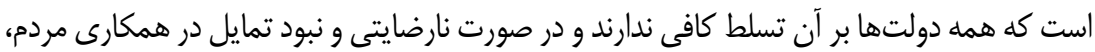

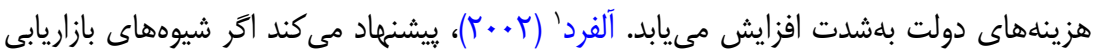
و مديريتي بكاركرفتهشده در بخش خصوصى براى بخش عمومى تطبيق داده شوند، مجموعئ.

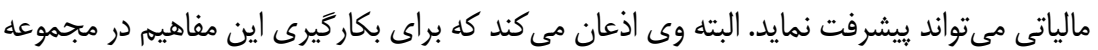

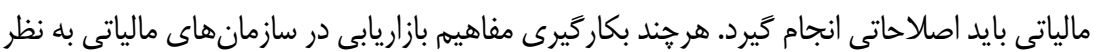

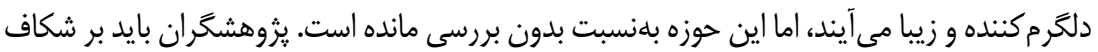
بين ساز مان هاى خصوصى و عمومى يلى ايجاد نمايند (Alford, 2002). بررسى تاثير ادراك بر رفتار موديان مالياتى در ادبيات بررسى شده است. جكسون و هاتفيلد؟

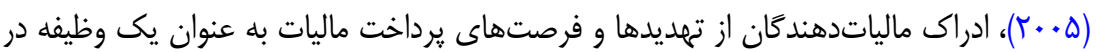

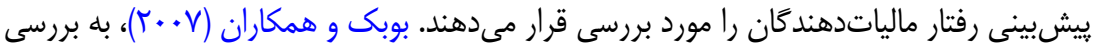
نظريه رفتار برنامهريزى شده در بيشبينى و تغيير رفتار مالياتدهندكان، در نظركَرفتن نقش اخلاق

\section{Alford}

2. Jackson \& Hatfield 
در يذيرش مالياتى و تاثير هنجارهاى اجتماعى و باورها و ادراك از ميزان كنترل فرد بر نيات رفتارى

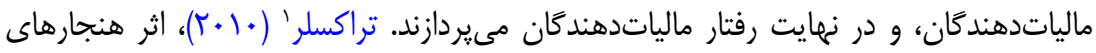
اجتماعى بر رفتار مالياتدهندكان را مورد بررسى قرار مى دهاند. يروهشهايى نيز با هدف بكارگيرى مفاهيم بازاريابى در حوزه ماليات انجام شده است. براى

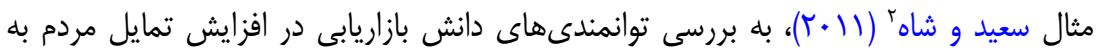

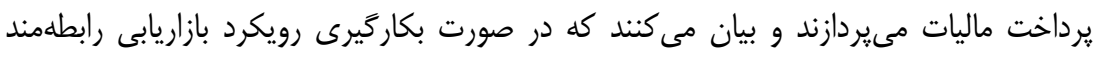

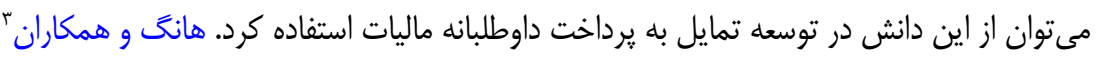

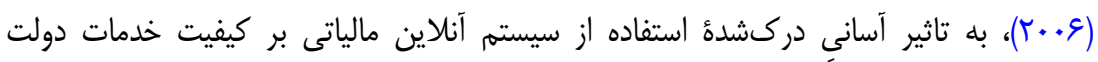

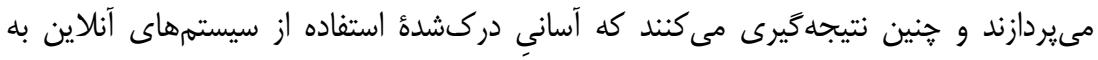

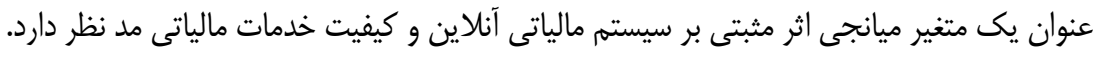

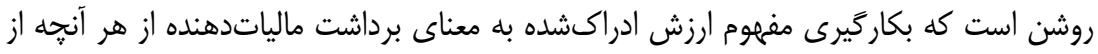

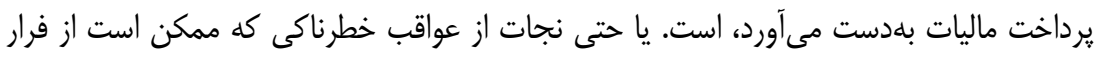

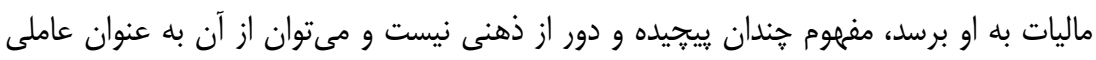

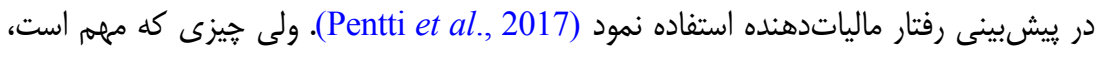

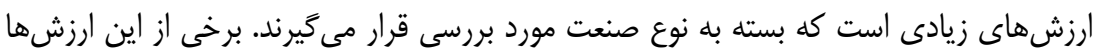

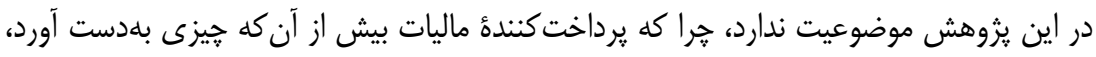

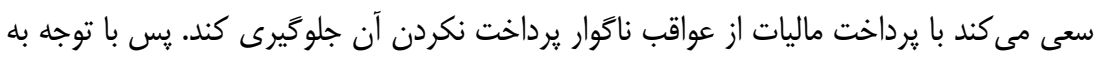

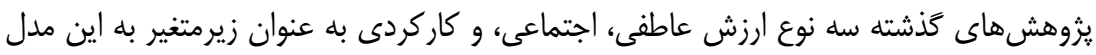

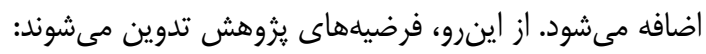

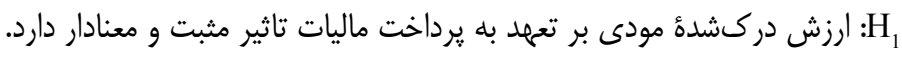
L H H H

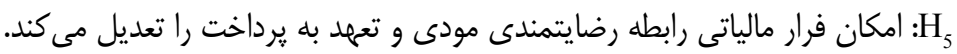

1. Traxler

2. Saeed \& Shah

3. Hung et al. 
شكل (()، مدل مفهومى يزوهش را بر اساس ادبيات نشان مىدهد.

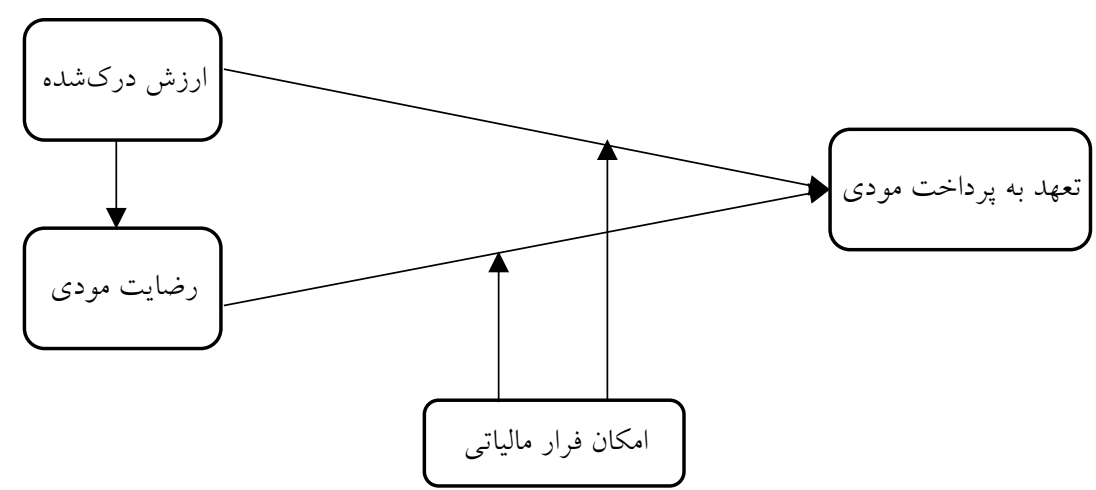

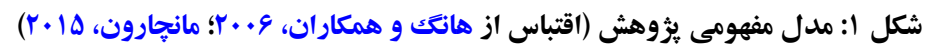

\section{روش}

جامعه آمارى اين يثوهش موديان مشمول قانون ماليات بر ارزشافزوده در استان كهيكيلويه

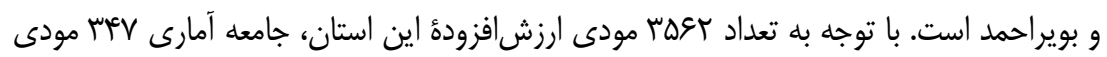

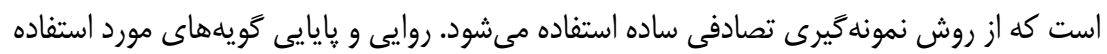

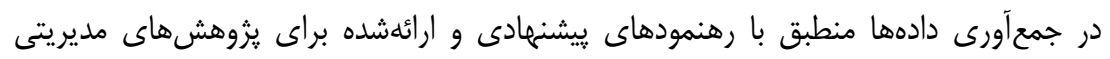

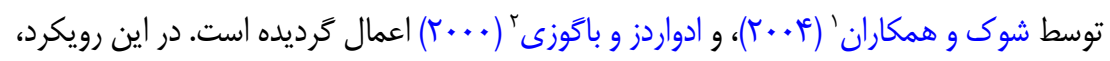

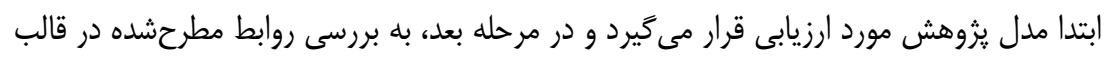

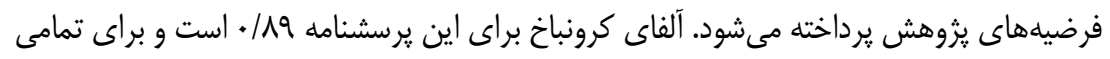

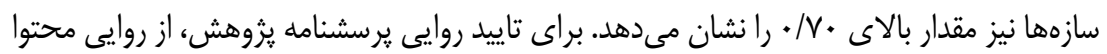

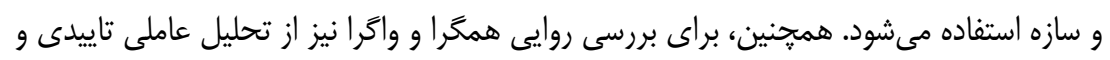

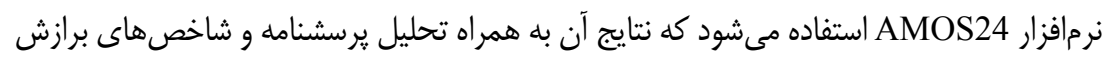
مدل (آلفا، AVE، و CRE) در جدول ( ) آمده است.

1. Shook et al.

2. Edwards \& Bagozzi 
جدول ا: نتايج شاخصهاى برازش مدل و تحليل عاملى تاييدى متغيرهاى بزوهش

\begin{tabular}{|c|c|c|c|c|c|c|}
\hline CR & آلفا AVE & مقدار & 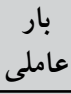 & ميانگين انحعراف & متغيرهاى يزوهش & ير برسشامه \\
\hline \multirow[t]{6}{*}{$\cdot / \Lambda \Lambda$} & $\cdot 191 \cdot 119$ & & & & ارزش عاطفى & \\
\hline & & & $\cdot / V \Delta$ & $\cdot / A V \quad Y / \cdot r$ & من از اينكه مالياتم را بهموقع و دقيق احساس خوبى دارم. & 1 \\
\hline & & IV/TY &.$/ 91$ & - /AD I/Ar & 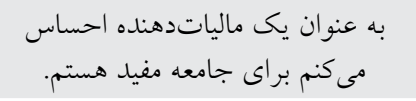 & r \\
\hline & & $18 / 49$ & $\cdot / \wedge \mathrm{V}$ & •/Ar I/91 & 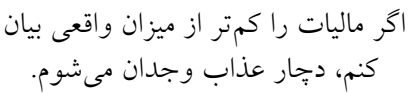 & $r$ \\
\hline & & $1 . / 99$ & $\cdot 19$ & $\cdot / \wedge \cdot \quad 1 / 94$ & اكر ماليات را كمتر از ميزان واقعى بيان & $\varphi$ \\
\hline & & $14 / 90$ & $\cdot / \mathrm{NA}$ & $\cdot / 19 \quad 1 / 90$ & ابراز ماليات كمتر از مقدار واقعى، & 0 \\
\hline$\cdot / \mathrm{AV}$ & $\cdot / 09 \cdot / 11$ & & & & ارزش اجتماعى & \\
\hline
\end{tabular}

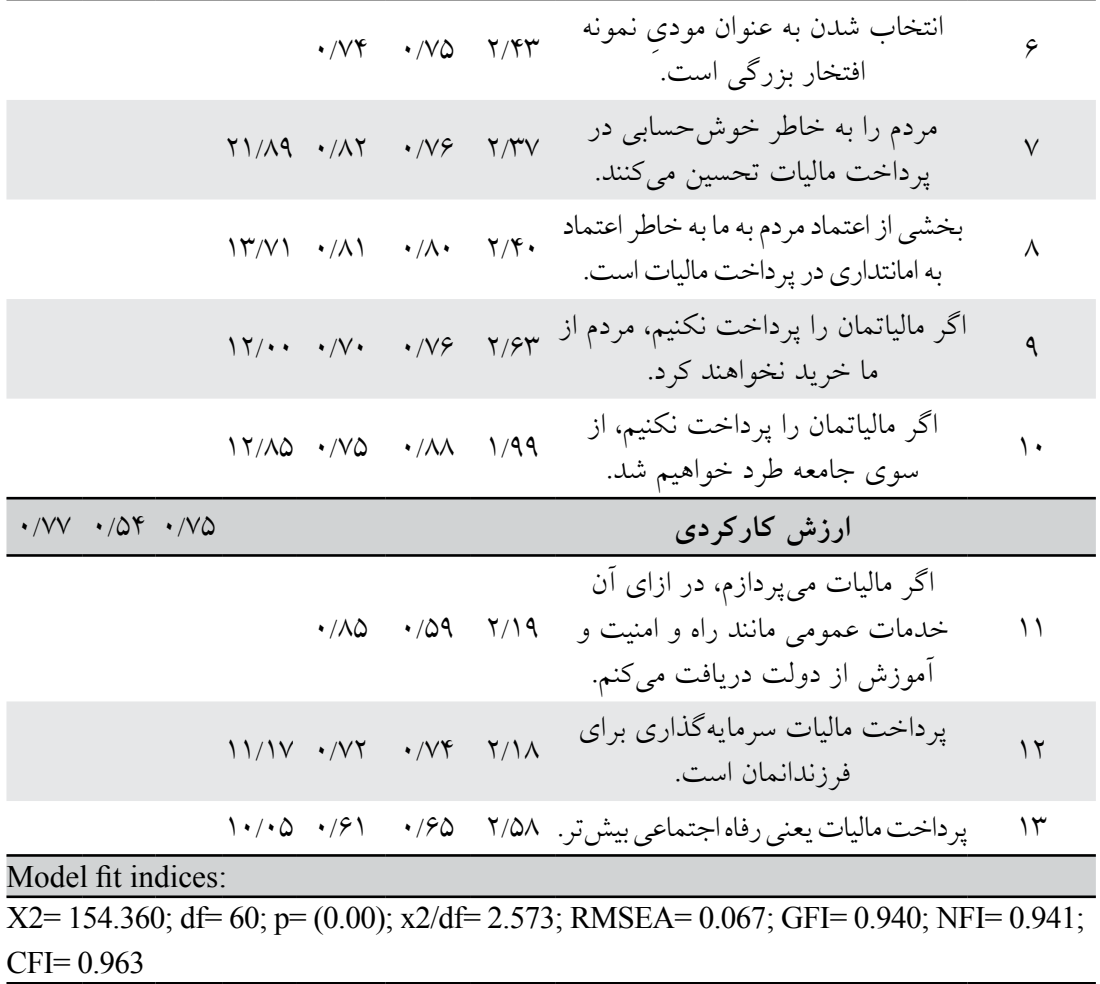


ادامه جدول ا: نتايج شاخصهاى برازش مدل و تحليل عاملى تاييدى متغيرهاى بزووهش

\begin{tabular}{|c|c|c|c|c|c|c|c|}
\hline CR & آلفا AVE & $\begin{array}{l}\text { مقدار } \\
\text { T }\end{array}$ & 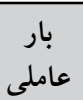 & انحراف & ميانخين & 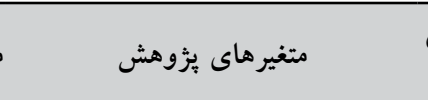 & 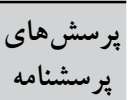 \\
\hline \multirow[t]{5}{*}{$\cdot / \mathrm{A} \mid$} & $\cdot / O r \cdot / \Lambda 1$ & & & & & رضايت از فرايند مصرف ماليات & \\
\hline & & & $\cdot / M^{c}$ & $\cdot / 94$ & $r / r)$ & ما به عنو ان شهروند بر نحوه مصرف ماثل ماليات & 14 \\
\hline & & $11 / 11$ & $\cdot / N r$ & $\cdot / 9 V$ & $r / Q T^{K}$ & هزينهكردماليات بسيار روشنوشفافاست. & 10 \\
\hline & & $11 / 9$ & $\cdot / M^{c}$ & $1 / \cdot 1$ & $r / \mu Q$ & خدمات دولت از اجراى قانون برابر شده اسزوده. & 19 \\
\hline & & $11 / \cdot V$ & $\cdot / 91$ & $1 / \cdot 1$ & $r / \mu r$ & 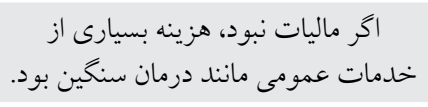 & IV \\
\hline \multirow[t]{5}{*}{$\cdot / 9$. } & $\cdot / V \cdot \cdot / 19$ & & & & & رضايت از فرايند مالياتستانى & \\
\hline & & & $\cdot / \wedge \vee$ & $1 / 1$ & $r / Y Y$ & فرايند اظهار و برداخت ماليات راحت & 11 \\
\hline & & $r M$ & $\cdot / \Lambda$ & $\cdot / 9 r$ & $r / r q$ & كارمندان مالياتى برخورد مناسبى دارند. & 19 \\
\hline & & IV/9V & $\cdot / \mathrm{V} q$ & I/Tr & $r / \mu r$ & 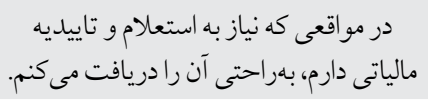 & r. \\
\hline & & IV/AG & $\cdot / \sqrt{ } 9$ & $\cdot / 91$ & $r /$. & فرايند مميزى و راستى آزمايى عادلانه است. & $r_{1}$ \\
\hline
\end{tabular}

\section{Model fit indices:}

$\mathrm{X} 2=27 ; \mathrm{df}=19 ; \mathrm{p}=(0.00) ; \mathrm{x} 2 / \mathrm{df}=1.42 ; \mathrm{RMSEA}=0.035 ; \mathrm{GFI}=0.982 ; \mathrm{NFI}=0.931 ; \mathrm{CFI}=0.994$ $\cdot / A Y \cdot / 01 \cdot / 11$

$$
\text { تعهد به برداخت ماليات }
$$

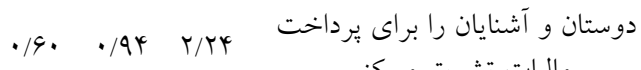

$$
\begin{aligned}
& \text { ماليات تشويق مىكنم. }
\end{aligned}
$$

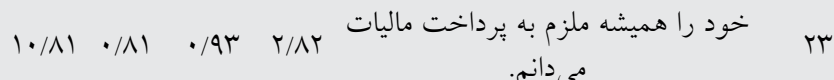

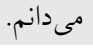

$$
\begin{aligned}
& \text { اكر حتى ميزان ماليات واقعى يرداخت }
\end{aligned}
$$

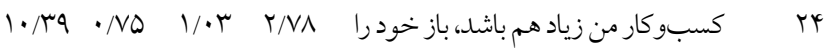

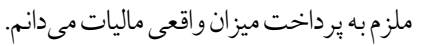

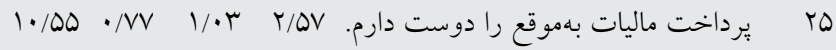

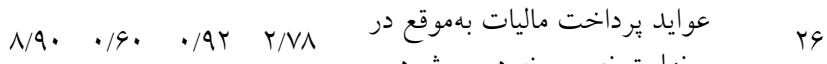

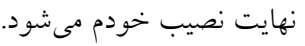

Model fit indices:

$\mathrm{X} 2=9.915 ; \mathrm{df}=4 ; \mathrm{p}=(0.00) ; \mathrm{x} 2 / \mathrm{df}=2.47 ; \mathrm{RMSEA}=0.065 ; \mathrm{GFI}=0.989 ; \mathrm{NFI}=0.985$;

$\mathrm{CFI}=0.991$ 
"r برسش ابتدايى يرسشنامه مفهوم ارزش دركشده و همجنين، متغيرهاى ينهان اين سازه

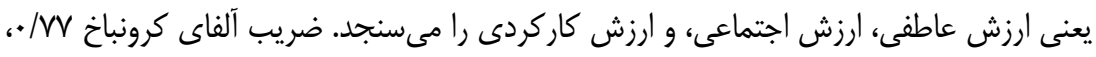

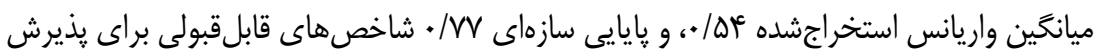
روايى و يايايى در سنجش اين متغير هستند. متغير ميانجى رضايتمندى در موديان بر اساس

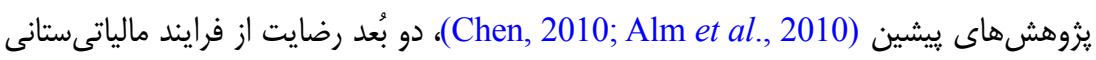
و فرايند هزينهكرد ماليات دارد، كه اولى در حوزه اختيارات سازمان امور مالياتى و دومى در

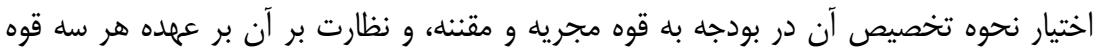

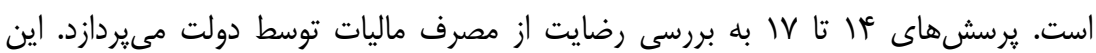

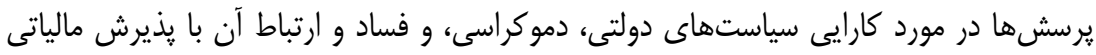

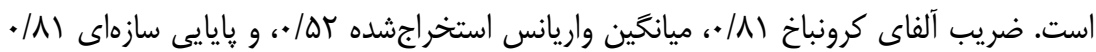

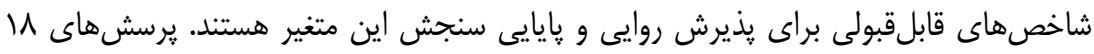

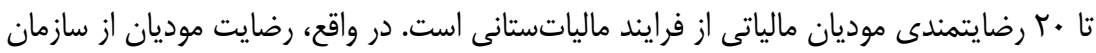

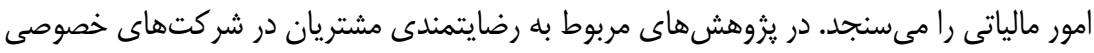

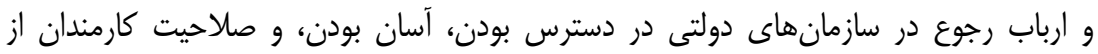

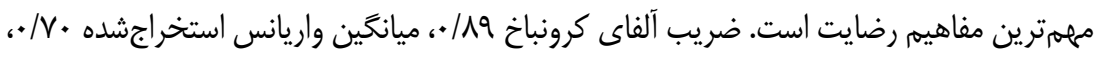

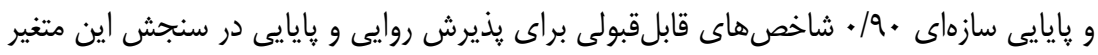

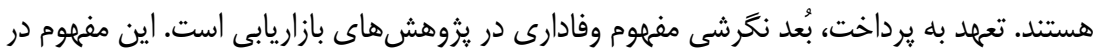

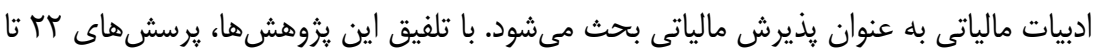

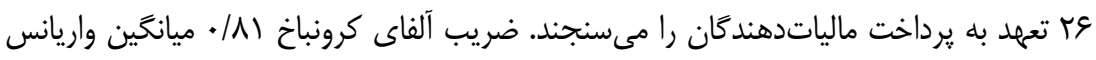

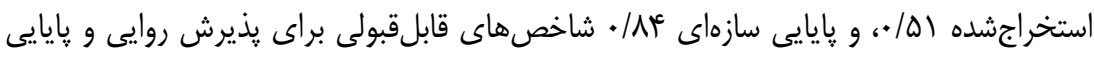
در سنجش اين متغير هستند.

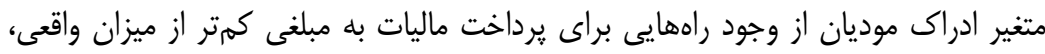

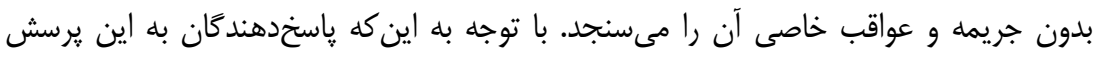

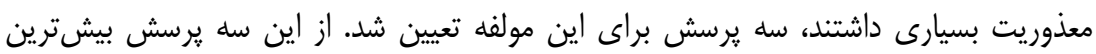

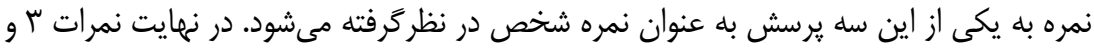

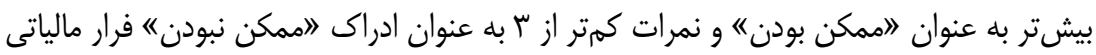

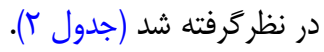


جدول ז: نتايج تحليل عاملى تاييدى امكان فرار مالياتى

\begin{tabular}{cccc}
\hline & & \\
\\
\end{tabular}

يافته ها

مدل مفهومى يزوهش حاضر داراى يك متغير مكنون برونزا به نام ارزش دركشده و دو متغير مكنون درونزا به نام رضايتمندى و وفادارى، و يك متغير تعديلكر به نام امكان فرار مالياتى است. يس تعيين روايى از طريق تحليل عاملى تاييدى، در ادامه با مدل معادلههاى ساختارى به تاييد يا رد فرضيههlى يزوهش يرداخته مىشود. معيار ما براى تاييد يا رد فرضيهها عدد معنادارى است. در कर

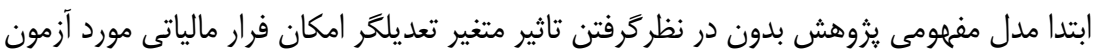

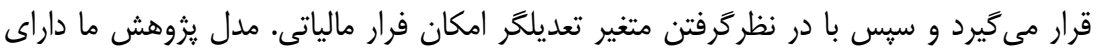
دو متغير مستقل، يك متغير ميانجى، يك متغير وابسته، و يك متغير تعديلخر است. براى محاسبه

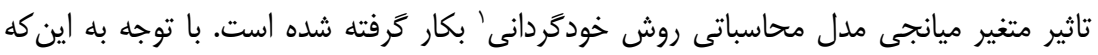

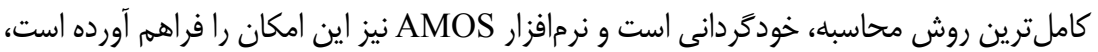
براى تاثير متغير ميانجى رضايتمندى از روش خودگردانى استفاده مى شود.

جدول rم: نتيجه بررسى تاثير متغير ميانجى (محاسبه به روش خودمردانى)

\begin{tabular}{|c|c|c|c|}
\hline اثر كل & اثر مستقيم & 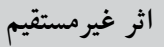 & رابطه - ت ابطه \\
\hline 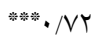 & 絭絭・19. & & ارزش دركشده -ـ تعهد به پرداخت \\
\hline & & $* \% * / 1 Y$ & ارزش دركشده —ـ رضايتمندى ــ تعهل به يرداخت \\
\hline
\end{tabular}

Notes: *** p-value $<0.01 ; * *$ p-value $<0.05$

Notes: $\mathrm{CMIN} / \mathrm{DF}=2.399 ; \mathrm{RAMSEA}=0.64 ; \mathrm{CFI}=0.917 ; \mathrm{IFI}=0.917 ; \mathrm{AGFI}=0.834$

1. Bootstrapping 


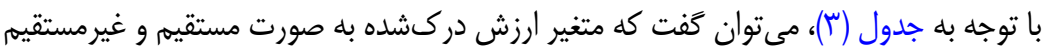
از طريق متغير رضايتمندى بر تعهد به يرداخت مودى اثر مى كذارد.

\section{آزمون متغير تعديلكر امكان فرار مالياتى}

متغير امكان فرار مالياتى ادراكشده به يك متغير دووجهى تبديل شده است، يا مودى هنين

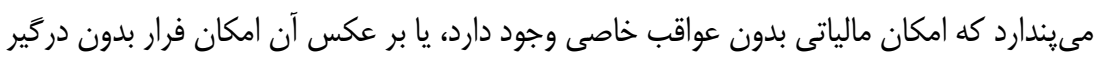
شدن با عواقب نامطلوب امكانيذير نيست. نتايج در جدول (أ) نمايش داده مىشودا.

جدول f^: آزمون تعديلكرى و معنادارى تفاوت دو كروه

\begin{tabular}{|c|c|c|c|c|c|c|c|}
\hline & & \multicolumn{2}{|c|}{ NoTem } & \multicolumn{2}{|c|}{ Tem } & \multicolumn{2}{|c|}{ معنادارى تفاوت دو گروه } \\
\hline & & Estimate & $\mathbf{P}$ & Estimate & $\mathbf{P}$ & z-score & نتيجه \\
\hline 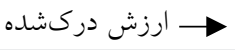 & رضايتمندى & $\cdot / \mu \wedge$ &.$/ \cdot 11$ &.$/ 90$ & $\cdot / \cdots$ & $1 / 91 V^{* * m_{*}^{*}}$ & معنادار \\
\hline$\rightarrow$ & تعهد & $\cdot / 490$ & $\cdot \cdots$ & $\cdot / 009$ & $\cdot / 10 \wedge$ & ./lQR & بى معنا \\
\hline 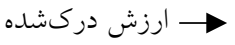 & تعهد & - MTY &.$/ \cdot 11$ & $1 / \pi 1$. & $\cdot 1 \cdot \cdot 9$ & $Y / \mid Y \varphi^{* * * * *}$ & معنادار \\
\hline
\end{tabular}

Notes: $* * *$ p-value $<0.01 ; * *$ p-value $<0.05$

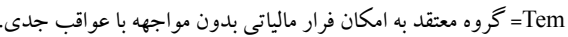
NoTem

جدول (أ)، نشان مىدهد كه با وجود اين متغير همجنان روابط بين متغيرهاى اصلى معنادار

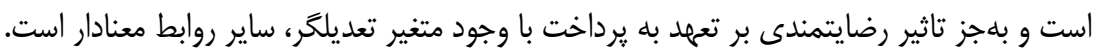

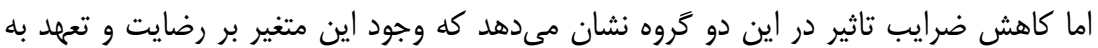
يرداخت موديان اثر منفى دارد.

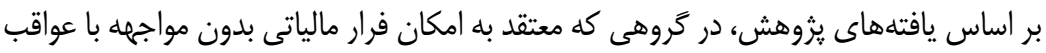

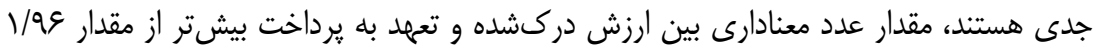
است. پس مىتوان كفت بين ارزش دركشده و تعهد به يرداخت ماليات رابطه مثبت و معنادارى وجود دارد و فرضيه H تاييد مىشود. همجنين، اثر ارزش دركشده مودى بر رضايتمندى وى

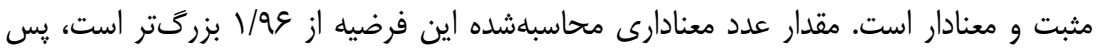
مىتوان كفت بين ارزش دركشده و رضايتمندى رابطه مثبت و معنادارى وجود دارد، و فرضيه

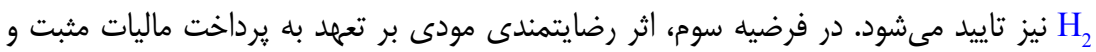


معنادار ارزيابى مىشود. مقدار عدد معنادارى محاسبهشده اين فرضيه از وه/ا بزرگتر است، در

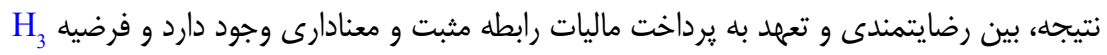
تابيد مىشود.

در فرضيه H4، متغير تعديلكَر امكان فرار مالياتى بر اثر ارزش دركشده بر تعهد به برداخت

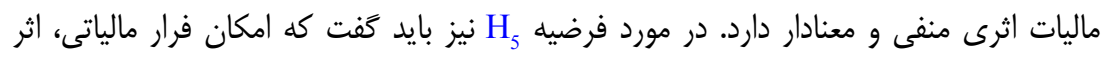

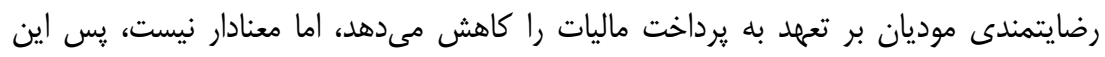
فرضيه را نمىتوان تاييد كرد.

بحث و نتيجه كيرى

هدف اين يزوهش، تحليل رابطه ارزش دركشده و تعهد به يرداخت ماليات با در نظركَرفتن

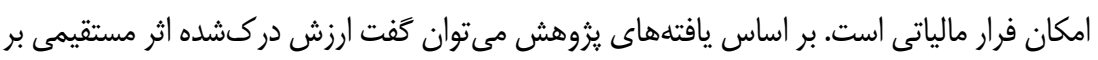

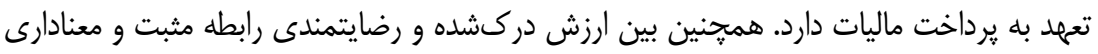

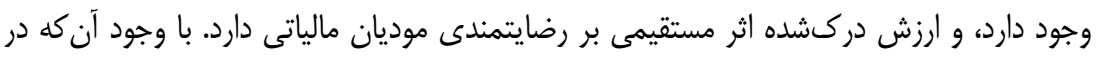

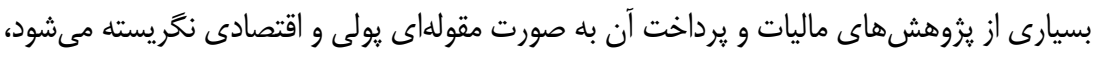

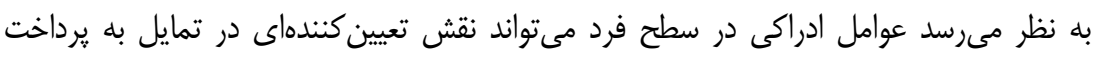

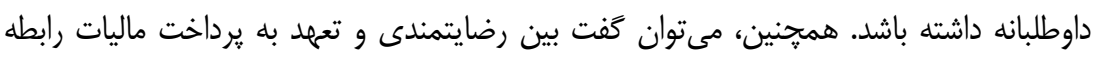

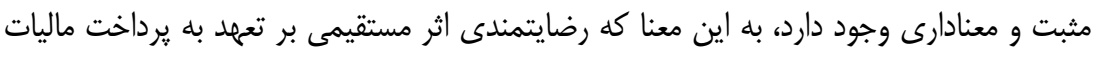

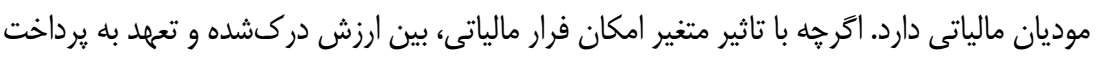
ماليات رابطه مثبت و معنادارى وجود دارد، اما اثر كاهشى معنادارى داشته است. اين بدان معناست

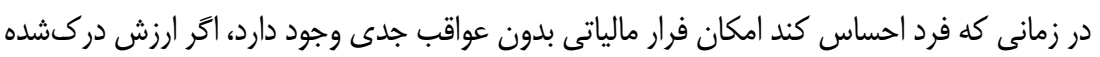

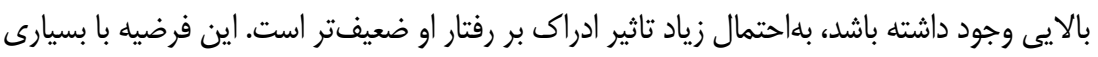

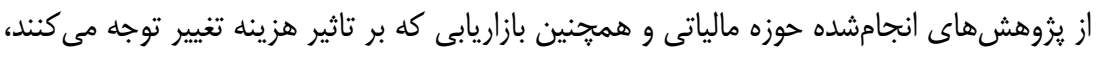

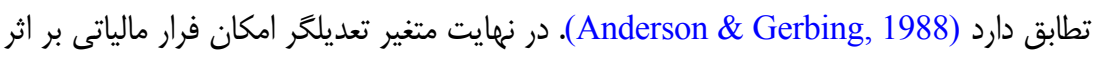

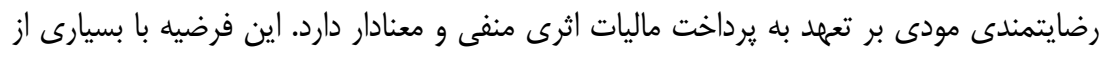

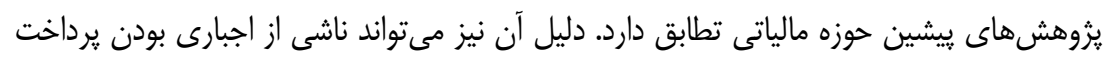

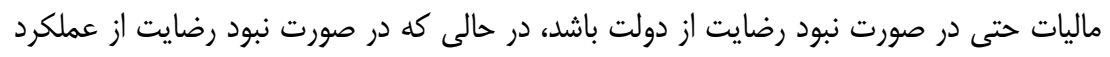

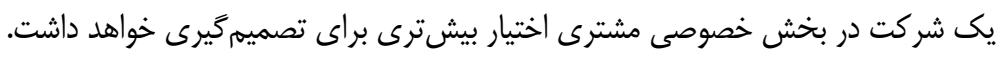

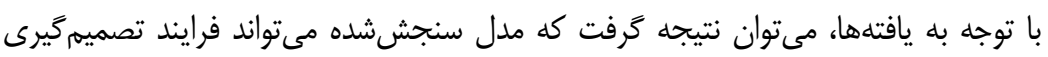


موديان مالياتى را تحليل نمايد و تا حدود زيادى يافتههاى ما با ادبيات حوزه روانشناسى اجتماعى دارى

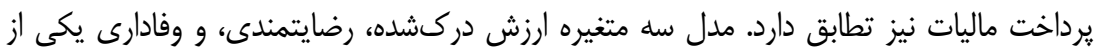

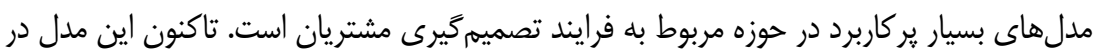

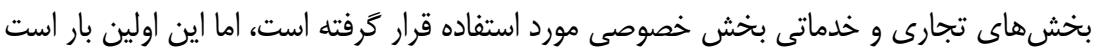

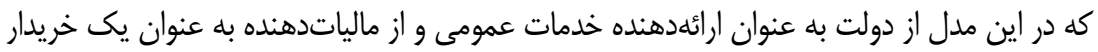

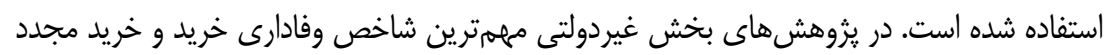

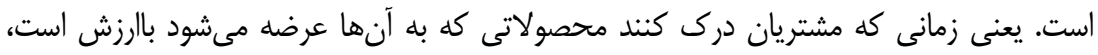

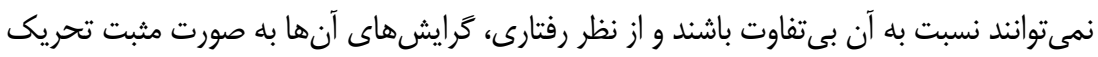

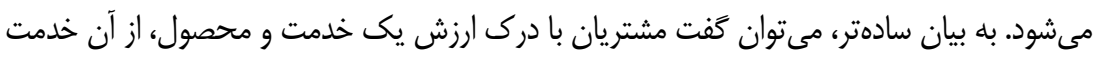

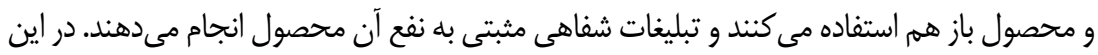

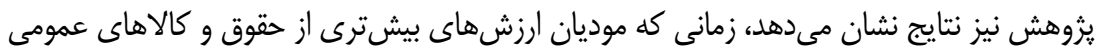

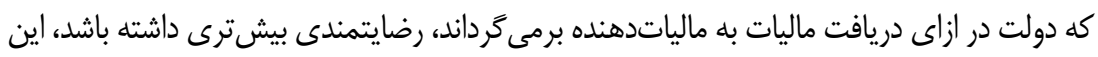

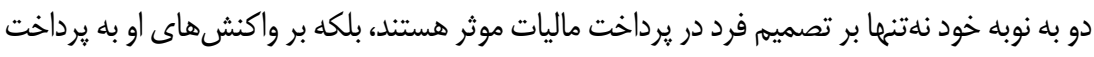

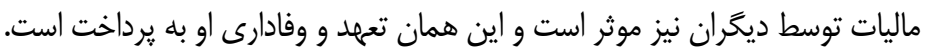

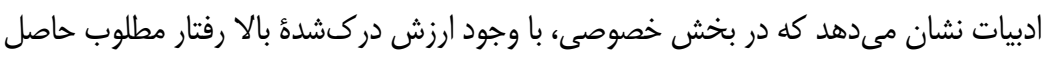

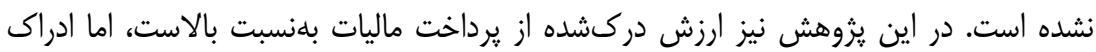

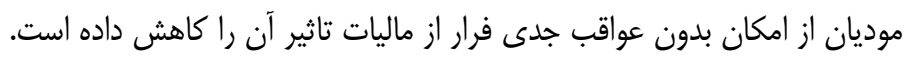

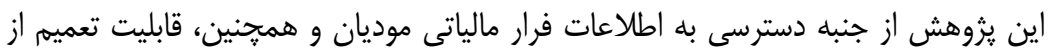

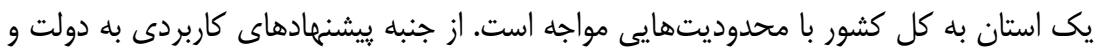

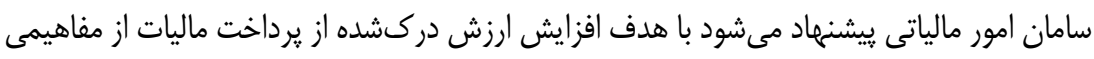

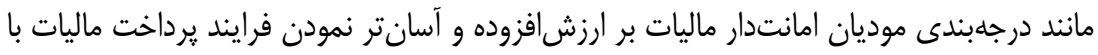

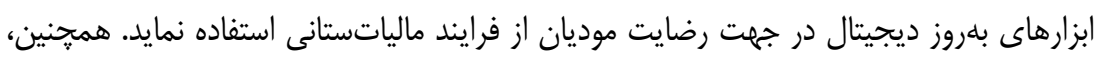

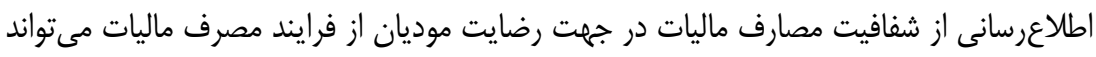

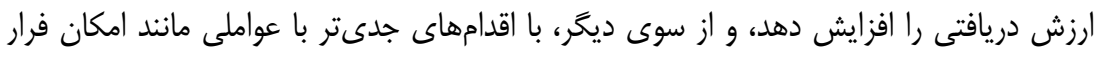

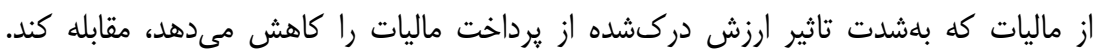

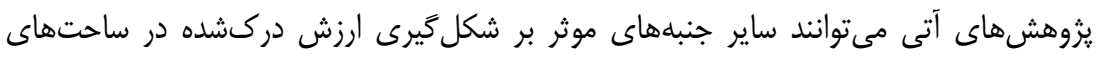

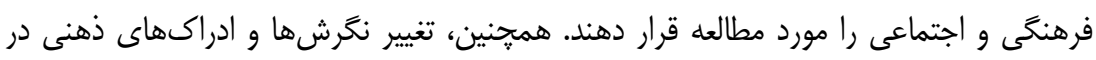

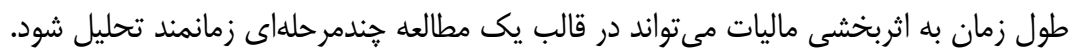




\section{منابع}

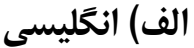

$$
\begin{aligned}
& \text { سميعى، عبدالمحمد (وعr(1). تحليلى بر نظام مالياتى، سياستهاى يولى و مالى دولت. نشريه فرايند مديريت }
\end{aligned}
$$

Alford, J. (2002). Defining the Client in the Public Sector: A SocialExchange Perspective. Public Administration Review, 62(3), 337-346. https://doi.org/10.1111/1540-6210.00183

Aljaaidi, K. S. Y., Manaf, N. A. A., \& Karlinsky, S. S. (2011). Tax Evasion as a Crime: A Survey of Perception in Yemen. International Journal of Business and Management, 6(9), 190-201.

Alm, J., Cherry, T., Jones, M., \& McKee, M. (2010). Taxpayer Information Assistance Services and Tax Compliance Behavior. Journal of Economic Psychology, 31(4), 577-586. https://doi.org/10.1016/j.joep.2010.03.018

Anderson, J. C., \& Gerbing, D. W. (1988). Structural Equation Modeling in Practice: A Review and Recommended Two-Step Approach. Psychological Bulletin, 103(3), 411-423. https://doi.org/10.1037/0033-2909.103.3.411

Bird, R. M., Martinez-Vazquez, J., \& Torgler, B. (2008). Tax Effort in Developing Countries and High-income Countries: The Impact of Corruption, Voice and Accountability. Economic Analysis and Policy, 38(1), 55-71. https://doi.org/10.1016/S0313-5926(08)50006-3

Bobek, D. D., Hatfield, R. C., \& Wentzel, K. (2007). An Investigation of Why Taxpayers Prefer Refunds: A Theory of Planned Behavior Approach. Journal of the American Taxation Association, 29(1), 93-111. https://doi.org/10.2308/jata.2007.29.1.93

Casal, S., Kogler, C., Mittone, L., \& Kirchler, E. (2016). Tax Compliance Depends on Voice of Taxpayers. Journal of Economic Psychology, 56(1), 141-150. https://doi.org/10.1016/j.joep.2016.06.005

Chen, C.-W. (2010). Impact of Quality Antecedents on Taxpayer Satisfaction with Online Tax-filing Systems-An Empirical Study. Information \& Management, 47(5-6), 308-315. https://doi.org/10.1016/j.im.2010.06.005

Devos, K. (2013). Factors Influencing Individual Taxpayer Compliance Behaviour: Springer Science \& Business Media. 
Edwards, J. R., \& Bagozzi, R. P. (2000). On the Nature and Direction of Relationships between Constructs and Measures. Psychological Methods, 5(2), 155-174. https://doi.org/10.1037/1082-989X.5.2.155

Evans, G. (2002). Measuring and Managing Customer Value. Work Study, 51(3), 134-139. https://doi.org/10.1108/00438020210424262

Floropoulos, J., Spathis, C., Halvatzis, D., \& Tsipouridou, M. (2010). Measuring the Success of the Greek Taxation Information System. International Journal of Information Management, 30(1), 47-56. https://doi.org/10.1016/j.ijinfomgt.2009.03.013

Herawati, H., Tabroni, R., \& Lusiana, S. (2018). The Effectiveness of the Tax Regulation Socialization Strategies on Tax Payers'Comprehension and Compliance in Implementing Their Tax Obligations. The International Journal of Business Review (The Jobs Review), 1(2), 131-140. https://doi.org/10.17509/tjr.v1i2.12980

Hung, S.-Y., Chang, C.-M., \& Yu, T.-J. (2006). Determinants of User Acceptance of the E-Government Services: The Case of Online Tax Filing and Payment System. Government Information Quarterly, 23(1), 97-122. https://doi.org/10.1016/j.giq.2005.11.005

Jackson, S. B., \& Hatfield, R. C. (2005). A Note on the Relation between Frames, Perceptions, and Taxpayer Behavior. Contemporary Accounting Research, 22(1), 145-164. https://doi.org/10.1506/L5LA-L863-CF9K-WEJ5

Kotler, P., \& Keller, K. L. (2006). Marketing Management: Edition Pearson Education.

Kotler, P., \& Lee, N. R. (2007). Marketing in the Public Sector: The Final Frontier. Public Manager, 36(1), 12-17.

Mancharoen, M. (2015). Determinants of Tax Evasion: Perception of Southern-Thailand Taxpayers. (Master of Science). Universiti Utara Malaysia,

Mojarab, E., Lagzian, M., \& Mortazavi, S. (2019). Phenomenography of Citizen Relationship Management. Quarterly Journal of Management and Development Process, 31(4), 133-164. http://jmdp.ir/article-1-3208-en.html

Oliver, R. L. (1999). Whence Consumer Loyalty? Journal of Marketing, 63(4_ suppl1), 33-44. https://doi.org/10.1177/00222429990634s105

Pentti, J., Juha, M., \& Outi, U. (2017). The Structure and Formation of Customer Value in B-to-B Services. In the Customer is NOT Always Right? Marketing Orientationsin a Dynamic Business World (pp. 237-241): Springer. https://doi.org/10.1007/978-3-319-50008-9_64

Saeed, A., \& Shah, A. (2011). Enhancing Tax Morale with Marketing Tactics: A Review of Literature. African Journal of Business Management, 5(35), 13559-13565. 
Shook, C. L., Ketchen Jr, D. J., Hult, G. T. M., \& Kacmar, K. M. (2004). An Assessment of the Use of Structural Equation Modeling in Strategic Management Research. Strategic Management Journal, 25(4), 397-404. https://doi.org/10.1002/smj.385

Sukesi, S., \& Yunaidah, I. (2020). The Effect of Tax Socialization, Superior Service, and Service Quality on Taxpayers' Satisfaction and Compliance. Journal of Economics, Business, and Accountancy Ventura, 22(3), 347-359. http://repository.unitomo.ac.id/id/eprint/3068

Sweeney, J. C. (2007). Moving Towards the Service-Dominant Logic-A Comment. Australasian Marketing Journal (AMJ), 15(1), 97-104. https://doi.org/10.1016/S1441-3582(07)70036-8

Sweeney, J. C., \& Soutar, G. N. (2001). Consumer Perceived Value: The Development of a Multiple Item Scale. Journal of Retailing, 77(2), 203220. https://doi.org/10.1016/S0022-4359(01)00041-0

Traxler, C. (2010). Social Norms and Conditional Cooperative Taxpayers. European Journal of Political Economy, 26(1), 89-103. https://doi.org/10.1016/j.ejpoleco.2009.11.001

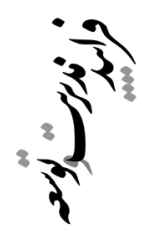

